\title{
What are the Effects of Computerized Decision Support Systems on Practitioner Performance and Patient Outcomes
}

Clemens Scott Kruse ( $\sim$ scottkruse@txstate.edu )

Texas State University San Marcos https://orcid.org/0000-0002-7636-1086 Nolan Ehrbar

Texas State University

\section{Research article}

Keywords: computerized decision support systems (CDSS), practitioner performance, patient outcomes, medical informatics

Posted Date: November 6th, 2019

DOI: https://doi.org/10.21203/rs.2.16890/v1

License: (c) (i) This work is licensed under a Creative Commons Attribution 4.0 International License.

Read Full License 


\section{Abstract}

Background Computerized decision support systems (CDSS) are software programs that support the decision making of practitioners and other staff. Other reviews have analyzed the relationship between CDSS, practitioner performance, and patient outcomes. These reviews reported positive practitioner performance in over half the articles analyzed, but very little information was found for patient outcomes. The purpose of this review was to analyze the relationship between CDSS, practitioner performance, and patient medical outcomes. PubMed, CINAHL, and Cochrane databases were queried.Methods 27 articles were chosen based on year published (last ten years), high quality source, and discussion of the relationship between the use of CDSS as an intervention and links to practitioner performance or patient outcomes. Reviewers used an Excel spreadsheet to collect information on the relationship between CDSS and practitioner performance or patient outcomes. Reviewers also collected observations of participants, intervention, comparison with control group, and outcomes (PICO) along with those showing implicit bias. Articles were analyzed by multiple reviewers following the Kruse Protocol for systematic reviews. Data were organized into multiple tables for analysis and reporting.Results Fourteen articles (52\%) discussed positive practitioner performance, three articles (11\%) found no difference in practitioner performance, ten articles (37\%) did not discuss practitioner performance. Zero articles reported negative practitioner performance. Fifteen articles (56\%) discussed positive patient medical outcomes, two articles (7\%) found no statistically significant difference in medical outcomes between intervention and control groups, and ten articles (37\%) did not discuss medical outcomes. Zero articles found negative patient medical outcomes.Conclusions Results of this review are commensurate with previous reviews with similar objectives, but unlike these reviews we found significant positive reporting of a positive effect on patient medical outcomes. Our findings support adoption of decision support systems.

\section{Background}

Rationale

Computerized decision support systems (CDSS) are software programs that support the decision making of practitioners and other staff. There are two major classes of CDSS the first being knowledge based CDSS and non-knowledge-based CDSS(1). Knowledge-based CDSS were the earliest classes of CDSS using a data repository to draw conclusions. Knowledge based systems use traditional computing methods giving programmed results. Non-knowledge based CDSS systems are growing rapidly and use Al assistance to make clinical decisions. Al supported CDSS uses patient data to analyze the relationships between symptoms, treatments, and patient outcomes to make clinical decisions. This patient data is usually derived from electronic health records: digital forms of patient records that include patient information such as personal contact information, patient's medical history, allergies, test results, and treatment plan(2). Data-mining: a process usually assisted by Al is often used by CDSS to identify new data patterns from large data sets (like patient EHR's), while Al is used for data mining, these conclusions can be used by both non-knowledge based CDSS and knowledge-based CDSS(3). CDSS systems are integrated into technologies such as computerized physician order entry (CPOE)(4) tools and 
electronic medical record (EMR) databases, they can use a wide variety of data to make clinical decisions such as drug data, patient data, treatment data, and more to provide the best recommendations for treatment. CDSS utility varies widely drawing conclusions about many different ailments, disorders, and syndromes, prospects for this technology may employ patient preferences or financial capabilities. In order to determine the effects of CDSS is having on practitioner performance and patient outcomes, we conducted a systematic review compiling data from studies to draw a renewed conclusion. Our research used a wide variety of peer reviewed journals gathered using PUBMED and CINAHL to ensure the quality of our study.

In prior studies, CDSS has proven to improve practitioner performance but the effects on patient outcomes were inconsistent and require further study. This review was conducted in 1998, evaluating studies since 1992(5). It found a benefit to physician performance in $66 \%$ of studies analyzed $(n=65)$, but only 14 of those analyzed discussed outcomes, so no conclusions were made. It was repeated in 2005 with a larger sample(6). It found a positive impact on physician performance in $64 \%$ of studies analyzed $(n=100)$, but again, effects on patient outcomes were insufficient to make generalizations. In 2010, a research protocol was registered to repeat the review, but no publication followed. In 2011, the review was repeated with a similar size of articles analyzed $(n=91)(7)$. It identified a positive effect of CDSS on practitioner performance for $57 \%$ of articles analyzed, however, consistent with previous reviews, no conclusions could be made concerning patient outcomes.

Since the last publication on this topic in 2011, CDSS has seen significant industry growth becoming more accessible, cost effective, reliable, and possessing greater computational power(8). In addition to these hardware improvements, the inclusion of software such as artificial intelligence (Al) programs are growing rapidly in CDSS use but as of yet these improvements have not been systemically reviewed to see the overarching impacts they are having on patient outcomes and practitioner performance.

\section{Objective}

The purpose of this study is to repeat the study from 1998 and 2005 to analyze the effects computerized decision support systems (CDSS) have on practitioner performance and patient outcomes. CDSS employment is rapidly growing especially with increased access to CDSS Al supported software, however the effects are understudied. Our goal is to review the effectiveness of CDSS technologies, their employment, and their overall utility. Our research also intends to identify inhibitors to adoption and causes of poor outcomes.

\section{Methods}

Eligibility Criteria

The methods followed a measurement tool for the assessment of multiple systemic reviews (AMSTAR) (9). The format of the review uses the Preferred Reporting Items for a Systemic Review and metaanalyses (PRISMA)(10). Conceptualization of the overall review follows the Kruse Protocol for writing 
systematic reviews in health-related program(11). Articles were eligible for inclusion if they were published in a peer-reviewed journal in the English language within the last 5 years, whose full text were available, and they addressed the elements of the objective statement: measures of effectiveness of CDSS on practitioner performance or patient outcomes. Barriers were not listed in the search terms, but reviewers watched for barriers listed in the articles analyzed. A 5-year window was justified because we wanted the research to be up to data and prior research on the same subject was made in the last several years. We limited the search to peer-reviewed journals to ensure some element of quality to the papers we were analyzing.

Information Sources

Three common research databases were queried: PUBMED (the web-based components of Medline, life science journal, and online books) and Cumulative Index of Nursing and Allied Health Literature (CINAHL), and Cochrane (reviews, control trials, methodologies, and health technology assessments).

Searches were conducted from February $25^{\text {th }}$ to February $28^{\text {th }} 2019$. These databases were chosen at the recommendation of the National Institutes of Health which recommends at least three databases: PubMed, Embase, and Cochrane(12). Our university does not have access to Embase, so CINAHL was chosen due to its wide availability to other researchers. This practice also follows the Kruse Protocol(11).

Search and Study Selection

Searches in each database were identical: "Clinical decision support systems" AND ("patient reported outcomes" OR "practitioner performance"). Articles were eligible for inclusion if they were published in the last 10 years and discussed both clinical decision support systems and either practitioner performance or patient reported outcomes.

\section{Results}

The 41 results from the search string in three databases were placed into an Excel spreadsheet and shared among reviewers for selection and analysis. Filters were applied in each database to capture only the last 10 years (Feb 28, 2009 - Feb 28, 2019). Reviewers independently removed duplicates and screened abstracts. A statistic of agreement, kappa, was calculated. The kappa score produced was .98 showing almost complete agreement on all reviewed articles $(13,14)$. The remaining 30 results were read in full for relevance. Observations for the 27 articles that remained were placed in an Excel spreadsheet for independent data analysis. Observations were summarized into affinity matrices for further analysis.

\section{Figure 1: Article search and selection process}

Data Collection Process and Data Items 
Reviewers collected standard PICO observations plus indications of either practitioner performance or patient medical outcomes. Bias was also noted. Following the Kruse Protocol, observations were distilled into themes for further analysis. A summary table of all observations is listed in Table 1. Articles are listed in reverse chronological order.

\section{Table 1: Summary of analysis}

Eleven themes were identified for practitioner performance, two of which were not discussed and no difference. These themes are listed in Table 2 and are listed in order of occurrence first for positive effect followed by no difference and not discussed.

\section{Table 2: Summary of themes identified for practitioner performance}

As illustrated, 14 of 27 (52\%) of articles analyzed identified ten unique positive indicators of practitioner performance $(15,18,19,23,25,28,29,31,35,36,38,39,40,41)$. Practitioner performance was reported as more accurate prescribing, improved screening of patients, improved overall performance, increased awareness of patients' conditions, improved follow-up due to better communication with patients, improved accuracy of diagnosis, improved documentation, improved benchmarking, improved care plans, and improved buy-in of CDSS. Of those that identified performance, $82 \%(14 / 17)$ identified positive effect on practitioner performance as a result of using CDSS. Ten articles (37\%) did not discuss practitioner performance $(16,17,20-22,24,26,30,32,34)$.

Eight themes were identified for patient medical outcomes, two of which were not discussed and no difference. These themes are listed in Table 3 by order of greatest occurrence for positive effect followed by no difference and not discussed.

\section{Table 3: Summary of themes identified for patient medical outcomes}

As illustrated, 15 of 27 (56\%) articles analyzed identified positive patient medical outcomes as a result of using CDSS $(18,22,24-26,28,30,32,34,35-37-39,41)$. Patient medical outcomes were reported as improved symptoms, improved efficacy of treatment, improved disease management, improved safety, improved mortality, improved screening ability, and improved feedback between patient and provider. Of those that reported a difference, $88 \%$ reported positive effect. Two articles $(7 \%)$ reported no statistical difference between control and intervention groups $(27,29)$. Ten articles $(37 \%)$ did not discuss patient medical outcomes $(15-17,19,20,21,23,27,31,33,40)$.

Bias

Appendix A provides a table of PICO (Patient/participants, intervention, comparison, outcome) and bias. Outcomes are reported in Table 1. Bias was similar across articles reviewed: Most research took place in 
one facility, organization, or state which is a form of selection bias. A sample taken from a limited geographic area is inherently limited in its ability to generalize results to the general population unless steps have been taken to ensure the sample is representative of the population.

\section{Discussion}

Our review methodology enabled a meticulous evaluation of the efficiency and effectiveness of CDSS for practitioners and patients. A summary of the findings from the review are listed in Table 1. Of the 27 articles analyzed that reported efficiency or effectiveness, 14 and 15 reported positive performance or outcomes, respectively. Ten articles did not report either practitioner performance or patient medical outcomes.

Commensurate with previous reviews on this topic, a majority of articles analyzed reported improvement in practitioner performance $(6,7)$, but contrary to these previous reviews, this review found articles that reported patient outcomes, and a majority of these were positive outcomes. Although ten articles did not discuss practitioner performance, only three articles reported no difference in productivity.

Practitioners using CDSS experienced more accurate prescribing, improved screening, improved productivity, increased awareness of needs of patients, improved follow-up with patients due to enhanced communication channels enabled by the application, improved accuracy, improved documentation, improved benchmarking, improved care plans, and overall improved buy-in for CDSS. Patients experienced improved symptoms, improved efficacy, improved disease management, improved safety, improved mortality, improved screening, and improved feedback. Although ten articles did not discuss patient medical outcomes, only two reported no statistical difference in outcomes between control and intervention groups.

\section{Limitations}

The limited group of articles for analysis was a limitation. Only 27 articles met the selection criteria. A larger group for analysis would strengthen the external validity of the results because we could be better assured that our group is representative of the population. The effects of selection bias were reduced through the use of multiple reviewers to screen and analyze articles (9). Only two reviewers screened abstracts and analyzed articles for themes. One additional reviewer might have increased the number of observations. Publication bias was reduced through the inclusion of grey literature that included more than just peer-reviewed material. We considered only articles published in the English language. It is possible that additional observations could have been gained by expanding the search to other languages. This review is also limited by the techniques used in the trials analyzed, and the statistics and effect sizes could not be combined due to the wide range used by the articles. We also did not analyze or compare the heuristics and algorithms used by CDSS systems within the studies. To compensate for a limitation from a similar review in 2005 , we expanded our analysis beyond randomized control trials to pre-post and other designs (6). 


\section{Conclusions}

Overall , CDSS technologies have been found to be efficient for practitioner performance and effective in patient medical outcomes, however a further in depth review of its effectiveness, in particular aspects, such as the avoidance of alert fatigue and extension of CDSS utility is important. Decision-support tools extend beyond the practitioner to the patient, and some tools are not software based, but based on patient-reported data (36). The implementation of CDSS can mutually benefit both practitioner and patient, and it shows great promise for healthcare in the future.

\section{Abbreviations}

AMSTAR: Assessment of Multiple Systemic Reviews

CDSS: Computerized Decision Support Systems

CINAHL: Cumulative Index of Nursing and Allied Health Literature

CPOE: Computerized Provider Order Entry

PICO: Participants, Intervention, Comparison (to control), Outcome

PRISMA: Preferred Reporting Items for Systematic Reviews and Meta Analyses

\section{Declarations}

Ethical Approval: No human participants were used for this review.

Consent for publication: Not applicable

Availability of data and material: Not applicable

Conflict of Interest: The authors declare that they have no competing interests

Funding: No funding was used in creation of this review

Contributions: NE drafted the initial introduction and discussion and analyzed the articles. CSK designed the review, served as senior editor, analyzed the articles, and wrote the final version of all sections. Special thanks to my assistant, Leah Frye, who helped organize the references.

Acknowledgements: Not applicable 


\section{References}

1. What is clinical decision support system (CDSS)? - definition from WhatIs.com. SearchHealthIT Web site. https://searchhealthit.techtarget.com/definition/clinical-decisionsupport-system-CDSS. Accessed Sep 30, 2019.

2. Medicare Cf, Baltimore, Medicaid Services 7500 Security Boulevard, Usa M. Overview. https://www.cms.gov/Medicare/E-Health/EHealthRecords/index.html. Updated 2012. Accessed Oct 1, 2019.

3. Han J, Kamber M, Pei Js. Data mining : Concepts and techniques. 3rd ed. ed. Elsevier/Morgan Kaufmann; 2012.

4. Dixon B. Inpatient computerized provider order entry (CPOE). 2009.

5. Hunt DL, Haynes RB, Hanna SE, Smith K. Effects of computer-based clinical decision support systems on physician performance and patient outcomes: A systematic review. JAMA. 1998;280(15):1339-1346.

6. Garg AX, Adhikari NKJ, McDonald H, et al. Effects of computerized clinical decision support systems on practitioner performance and patient outcomes: A systematic review. JAMA. 2005;293(10):1223-1238.

7. Jaspers MWM, Smeulers M, Vermeulen H, Peute LW. Effects of clinical decision-support systems on practitioner performance and patient outcomes: A synthesis of high-quality systematic review findings. J Am Med Inform Assoc. 2011;18(3):327-334. doi:

10.1136/amiajnl-2011-000094.

8. Sim I, Gorman P, Greenes RA, et al. Clinical decision support systems for the practice of evidence-based medicine. J Am Med Inform Assoc. 2001;8(6):527-534. doi: 10.1136/jamia.2001.0080527.

9. Shea BJ, Grimshaw JM, Wells GA, et al. Development of AMSTAR: A measurement tool to assess the methodological quality of systematic reviews. BMC Medical Research Methodology. 2007;7:10-7. doi: 10.1186/1471-2288-7-10. 
10. Moher D, Liberati A, Tetzlaff J, Altman DG. Reprint -- preferred reporting items for systematic reviews and meta-analyses: The PRISMA statement...reprinted with permission from the annals of internal medicine from mother D, liberati A, tetzlaff J, altman DG. the PRISMA group. preferred reporting items for systematic reviews and meta-analyses: The PRISMA statement. Phys Ther. 2009;89(9):873-880.

11. Kruse CS. "Writing a Systematic Review for Publication in a Health-Related Degree Program.” JMIR Research Protocols, vol. 8, no. 10, Oct. 2019, p. e15490. doi:10.2196/15490.

12. Systematic review service. https://www.nihlibrary.nih.gov/services/systematic-reviewservice. Updated 2019.

13. McHugh ML. Interrater reliability: The kappa statistic. Biochemia Medica. 2012;22(3):276-282.

14. Light RJ. Measures of response agreement for qualitative data: Some generalizations and alternatives. Psychol Bull. 1971;76(5):365-377.

15. Kirby AM, Kruger B, Jain R, O'Hair DP, Granger BB. Using clinical decision support to improve referral rates in severe symptomatic aortic stenosis: A quality improvement initiative. CIN COMPUT INFORM NURS. 2018;36(11):525-529. doi:

10.1097/CIN.0000000000000471.

16. Dolan JG, Veazie PJ. The feasibility of sophisticated multicriteria support for clinical decisions. Med Decis Making. 2018;38(4):465-475. doi: 10.1177/0272989X17736769.

17. Con D, Jackson BD, De Cruz P. Design considerations for an eHealth decision support tool in inflammatory bowel disease self-management. Intern Med J. 2018;48(6):674-681. doi: $10.1111 / \mathrm{imj} .13677$.

18. Mooney KH, Beck SL, Wong B, et al. Automated home monitoring and management of patient-reported symptoms during chemotherapy: Results of the symptom care at home RCT. Cancer Medicine. 2017;6(3):537-546. doi: 10.1002/cam4.1002. 
19. Baypinar F, Kingma H, Hoeven R, Becker M. Physicians' compliance with a clinical decision support system alerting during the prescribing process. J Med Syst. 2017;41(6):1-6. doi: 10.1007/s10916-017-0717-4.

20. Zini, E. M. ( 1 ), Lanzola, G. ( 1 ), Quaglini, S. ( 1 ), Bossi, P. ( 2 ). An environment for guideline-based decision support systems for outpatients monitoring. Methods Inf Med. 2017;56(4):283-293. doi: 10.3414/ME16-01-0142.

21. Muro N, Larburu N, Bouaud J, Seroussi B. Weighting experience-based decision support on the basis of clinical outcomes' assessment. Stud Health Technol Inform. 2017;244:33-37.

22. Kistler CE, Golin C, Morris C, et al. Design of a randomized clinical trial of a colorectal cancer screening decision aid to promote appropriate screening in community-dwelling older adults. CLINICAL TRIALS. 2017;14(6):648-658. doi: 10.1177/1740774517725289.

23. Lawes S, Grissinger M. Medication errors attributed to health information technology. PENN PATIENT SAF ADVIS. 2017;14(1):1-8.

24. Cox, J.L. ( 1,2 ), Pieper, K. ( 3 ). Harnessing the power of real-life data. European Heart Journal, Supplement. 2015;17:D9-D14. doi: 10.1093/eurheartj/suv036.

25. Zhu X, Cimino JJ. Clinicians' evaluation of computer-assisted medication summarization of electronic medical records. Comput Biol Med. 2015;59:221-231. doi: 10.1016/j.compbiomed.2013.12.006.

26. Utidjian LH, Hogan A, Michel J, et al. Clinical decision support and palivizumab: A means to protect from respiratory syncytial virus. Appl Clin Inform. 2015;6(4):769-784. doi: 10.4338/ACI-2015-08-RA-0096.

27. Semler MW, Weavind L, Hooper MH, et al. An electronic tool for the evaluation and treatment of sepsis in the ICU: A randomized controlled trial. Crit Care Med. 2015;43(8):1595-1602. doi: 10.1097/CCM.0000000000001020. 
28. Peiris D, Usherwood T, Panaretto K, et al. Effect of a computer-guided, quality improvement program for cardiovascular disease risk management in primary health care: The treatment of cardiovascular risk using electronic decision support cluster-randomized trial. Circulation: Cardiovascular Quality and Outcomes. 2015(1):87. doi: 10.1161/CIRCOUTCOMES.114.001235.

29. Chow ALP, Lye DC, Arah OA. Mortality benefits of antibiotic computerised decision support system: Modifying effects of age. SCIENTIFIC REPORTS. 2015;5. doi: 10.1038/srep17346.

30. Wilson, C.J. ( 1,2 ), Flight, I.H. ( 1,2,3 ), Cole, S. R. ( 1 ), et al. A randomised controlled trial of personalised decision support delivered via the internet for bowel cancer screening with a faecal occult blood test: The effects of tailoring of messages according to social cognitive variables on participation. BMC Medical Informatics and Decision Making. 2015;15(1). doi: 10.1186/s12911-015-0147-5.

31. Loeb D, Sieja A, Corral J, Nichole G. Z, Gretchen G, Donald E. N. Evaluation of the role of training in the implementation of a depression screening and treatment protocol in 2 academic outpatient internal medicine clinics utilizing the electronic medical record. American Journal of Medical Quality. 2015(4):359. doi: 10.1177/1062860614532681.

32. Mishuris RG, Linder JA, Bates DW, Bitton A. Using electronic health record clinical decision support is associated with improved quality of care. Am J Manag Care. 2014;20(10):e445-e452.

33. Dexheimer JW, Abramo TJ, Arnold DH, et al. Implementation and evaluation of an integrated computerized asthma management system in a pediatric emergency department: A randomized clinical trial. Int J Med Inf. 2014;83(11):805-813. doi: 10.1016/j.ijmedinf.2014.07.008.

34. Heisler M, Choi H, Palmisano G, et al. Comparison of community health worker-led diabetes medication decision-making support for low-income latino and african american 
adults with diabetes using e-health tools versus print materials: A randomized, controlled trial. Ann Intern Med. 2014;161(10):S13-S22. doi: 10.7326/M13-3012.

35. Eckman MH, Wise RE, Speer B, et al. Integrating real-time clinical information to provide estimates of net clinical benefit of antithrombotic therapy for patients with atrial fibrillation. CIRCULATION-CARDIOVASCULAR QUALITY AND OUTCOMES. 2014;7(5):680-686. doi: 10.1161/CIRCOUTCOMES.114.001163.

36. Zaslansky R, Rothaug J, Chapman RC, et al. PAIN OUT: An international acute pain registry supporting clinicians in decision making and in quality improvement activities. $J$ Eval Clin Pract. 2014;20(6):1090-1098. doi: 10.1111/jep.12205.

37. Lobach D, Kawamoto K, Anstrom K, et al. A randomized trial of population-based clinical decision support to manage health and resource use for Medicaid beneficiaries. $J$ Med Syst. 2013;37(1):1-10. doi: 10.1007/s10916-012-9922-3.

38. Barlow J, Krassas G. Improving management of type 2 diabetes findings of the Type2Care clinical audit. Aust Fam Physician. 2013;42(1-2):57-60.

39. Robbins GK, Lester W, Johnson KL, et al. Efficacy of a clinical decision-support system in an HIV practice: A randomized trial. Ann Intern Med. 2012(11):757.

40. Chen C(, Chen K, Hsu C, Li Y(. Developing guideline-based decision support systems using protégé and jess. Comput Methods Programs Biomed. 2011;102(3):288-294. doi: 10.1016/j.cmpb.2010.05.010.

41. Seow H, King S, Green E, Pereira J, Sawka C. Perspectives of patients on the utility of electronic patient-reported outcomes on cancer care. J Clin Oncol. 2011;29(31):4213-4214. doi: 10.1200/JCO.2011.37.9750.

\section{Tables}

Table 1: Summary of analysis 


\begin{tabular}{|c|c|c|c|c|c|}
\hline Authors_ & Study & $\begin{array}{c}\text { Efficiency } \\
\text { (practitioner } \\
\text { performance) }\end{array}$ & $\begin{array}{l}\text { Efficiency } \\
\text { themes }\end{array}$ & $\begin{array}{c}\text { Effectiveness } \\
\text { (medical } \\
\text { outcomes) }\end{array}$ & $\begin{array}{c}\text { Effectiveness } \\
\text { themes }\end{array}$ \\
\hline $\begin{array}{l}\text { Kirby et al } \\
\text { (15) }\end{array}$ & $\begin{array}{l}\text { Using Clinical } \\
\text { Decision } \\
\text { Support to } \\
\text { Improve } \\
\text { Referral Rates } \\
\text { in Severe } \\
\text { Symptomatic } \\
\text { Aortic Stenosis: } \\
\text { A Quality } \\
\text { Improvement } \\
\text { Initiative }\end{array}$ & $\begin{array}{l}\text { Increased referral } \\
\text { awareness by providers } \\
\text { for pts with severe } \\
\text { aortic stenosis (which } \\
\text { is a known quality } \\
\text { issue). Increase in } \\
\text { referral rate from } 72 \% \\
\text { to } 97.5 \% \text {. }\end{array}$ & $\begin{array}{l}\text { Increased } \\
\text { awareness }\end{array}$ & $\begin{array}{l}\text { Medical outcomes } \\
\text { not discussed }\end{array}$ & $\begin{array}{l}\text { Not } \\
\text { discussed }\end{array}$ \\
\hline $\begin{array}{l}\text { Dolan \& } \\
\text { Veazie } \\
(16)\end{array}$ & $\begin{array}{l}\text { The Feasibility } \\
\text { of } \\
\text { Sophisticated } \\
\text { Multicriteria } \\
\text { Support for } \\
\text { Clinical } \\
\text { Decision }\end{array}$ & $\begin{array}{l}\text { Practitioner } \\
\text { performance not } \\
\text { discussed }\end{array}$ & Not discussed & $\begin{array}{l}\text { Medical outcomes } \\
\text { not discussed }\end{array}$ & $\begin{array}{l}\text { Not } \\
\text { discussed }\end{array}$ \\
\hline $\begin{array}{l}\text { Jackson \& } \\
\text { De Cruz } \\
\text { (17) }\end{array}$ & $\begin{array}{l}\text { Design } \\
\text { considerations } \\
\text { for an eHealth } \\
\text { decision } \\
\text { support tool in } \\
\text { inflammatory } \\
\text { bowel disease } \\
\text { self- } \\
\text { management. }\end{array}$ & $\begin{array}{l}\text { Practitioner } \\
\text { performance not } \\
\text { discussed }\end{array}$ & Not discussed & $\begin{array}{l}\text { Medical outcomes } \\
\text { not discussed }\end{array}$ & $\begin{array}{l}\text { Not } \\
\text { discussed }\end{array}$ \\
\hline $\begin{array}{l}\text { Mooney et } \\
\text { al (18) }\end{array}$ & $\begin{array}{l}\text { Automated } \\
\text { home } \\
\text { monitoring and } \\
\text { management of } \\
\text { patient- } \\
\text { reported } \\
\text { symptoms } \\
\text { during } \\
\text { chemotherapy: } \\
\text { results of the } \\
\text { symptom care } \\
\text { at home RCT } \\
\end{array}$ & $\begin{array}{l}\text { enabled providers to } \\
\text { follow up based on } \\
\text { feedback from patients }\end{array}$ & $\begin{array}{l}\text { Better follow } \\
\text { up with pts }\end{array}$ & $\begin{array}{l}\text { Intervention group } \\
\text { demonstrated } \\
\text { fewer severe and } \\
\text { moderate } \\
\text { symptoms }\end{array}$ & $\begin{array}{l}\text { Improved } \\
\text { symptoms }\end{array}$ \\
\hline $\begin{array}{l}\text { Baypinar } \\
\text { et al (19) }\end{array}$ & $\begin{array}{l}\text { Physicians' } \\
\text { Compliance } \\
\text { with a Clinical } \\
\text { Decision } \\
\text { Support } \\
\text { System } \\
\text { Alerting during } \\
\text { the Prescribing } \\
\text { Process } \\
\end{array}$ & $\begin{array}{l}\text { Correct prescribing } \\
\text { increased from } 54 \text { to } \\
91 \%(P<.014) \text { for folic } \\
\text { acid, } 11 \text { to } 40 \% \\
(P<.001) \text { for vitamin } D \text {, } \\
\text { and stopped orders } \\
\text { increased from } 3 \text { to } \\
14 \%(P<.002)\end{array}$ & $\begin{array}{l}\text { More accurate } \\
\text { prescribing }\end{array}$ & $\begin{array}{l}\text { Medical outcomes } \\
\text { not discussed }\end{array}$ & $\begin{array}{l}\text { Not } \\
\text { discussed }\end{array}$ \\
\hline $\begin{array}{l}\text { Zini et al } \\
(20)\end{array}$ & $\begin{array}{l}\text { An } \\
\text { Environment } \\
\text { for Guideline- } \\
\text { based Decision } \\
\text { Support } \\
\text { Systems for } \\
\text { Outpatients } \\
\text { Monitoring }\end{array}$ & $\begin{array}{l}\text { Practitioner } \\
\text { performance not } \\
\text { discussed }\end{array}$ & Not discussed & $\begin{array}{l}\text { Medical outcomes } \\
\text { not discussed }\end{array}$ & $\begin{array}{l}\text { Not } \\
\text { discussed }\end{array}$ \\
\hline
\end{tabular}




\begin{tabular}{|c|c|c|c|c|c|}
\hline Authors_ & Study & $\begin{array}{c}\text { Efficiency } \\
\text { (practitioner } \\
\text { performance) }\end{array}$ & $\begin{array}{l}\text { Efficiency } \\
\text { themes }\end{array}$ & $\begin{array}{c}\text { Effectiveness } \\
\text { (medical } \\
\text { outcomes) }\end{array}$ & $\begin{array}{c}\text { Effectiveness } \\
\text { themes }\end{array}$ \\
\hline $\begin{array}{l}\text { Muro et al } \\
\text { (21) }\end{array}$ & $\begin{array}{l}\text { Weighting } \\
\text { Experience- } \\
\text { Based Decision } \\
\text { Support on the } \\
\text { Basis of } \\
\text { Clinical } \\
\text { Outcomes' } \\
\text { Assessment }\end{array}$ & $\begin{array}{l}\text { Practitioner } \\
\text { performance not } \\
\text { discussed }\end{array}$ & Not discussed & $\begin{array}{l}\text { Medical outcomes } \\
\text { not discussed }\end{array}$ & $\begin{array}{l}\text { Not } \\
\text { discussed }\end{array}$ \\
\hline $\begin{array}{l}\text { Kistler et } \\
\text { al (22) }\end{array}$ & $\begin{array}{l}\text { Design of a } \\
\text { randomized } \\
\text { clinical trial of } \\
\text { a colorectal } \\
\text { cancer } \\
\text { screening } \\
\text { decision aid to } \\
\text { promote } \\
\text { appropriate } \\
\text { screening in } \\
\text { community- } \\
\text { dwelling older } \\
\text { adults }\end{array}$ & $\begin{array}{l}\text { Practitioner } \\
\text { performance not } \\
\text { discussed }\end{array}$ & Not discussed & $\begin{array}{l}\text { More patients } \\
\text { agreed to } \\
\text { screening in the } \\
\text { intervention group } \\
\text { than the control }\end{array}$ & $\begin{array}{l}\text { Improved } \\
\text { screening }\end{array}$ \\
\hline $\begin{array}{l}\text { Lawes \& } \\
\text { Grissinger } \\
\text { (23) }\end{array}$ & $\begin{array}{l}\text { Medication } \\
\text { Errors } \\
\text { Attributed to } \\
\text { Health } \\
\text { Information } \\
\text { Technology }\end{array}$ & $\begin{array}{l}\text { Practitioners } \\
\text { performed worse when } \\
\text { CDS was not available } \\
\text { or when incorrect data } \\
\text { were entered for } \\
\text { weight }\end{array}$ & $\begin{array}{l}\text { More accurate } \\
\text { prescribing }\end{array}$ & $\begin{array}{l}\text { Adverse drug } \\
\text { events no doubt } \\
\text { occurred as a } \\
\text { result of error, but } \\
\text { no outcomes were } \\
\text { discussed }\end{array}$ & $\begin{array}{l}\text { Not } \\
\text { discussed }\end{array}$ \\
\hline $\begin{array}{l}\text { Cox \& } \\
\text { Pieper } \\
\text { (24) }\end{array}$ & $\begin{array}{l}\text { Harnessing the } \\
\text { power of real- } \\
\text { life data }\end{array}$ & $\begin{array}{l}\text { Practitioner } \\
\text { performance not } \\
\text { discussed }\end{array}$ & Not discussed & $\begin{array}{l}\text { Treatment in the } \\
\text { doxazosin arm was } \\
\text { stopped early due } \\
\text { to a } 1.25 \text {-fold } \\
\text { increase in the } \\
\text { incidence of } \\
\text { combined CVD and } \\
\text { a two-fold increase } \\
\text { in the incidence of } \\
\text { heart failure } \\
\text { compared with the } \\
\text { diuretic arm }\end{array}$ & $\begin{array}{l}\text { Improved } \\
\text { efficacy }\end{array}$ \\
\hline $\begin{array}{l}\text { Zhu \& } \\
\text { Cimino } \\
\text { (25) }\end{array}$ & $\begin{array}{l}\text { Clinicians' } \\
\text { evaluation of } \\
\text { computer- } \\
\text { assisted } \\
\text { medication } \\
\text { summarization } \\
\text { of electronic } \\
\text { medical } \\
\text { records. }\end{array}$ & Accuracy improved & $\begin{array}{l}\text { Improved } \\
\text { accuracy }\end{array}$ & $\begin{array}{l}\text { Improved patient } \\
\text { safety }\end{array}$ & $\begin{array}{l}\text { Improved } \\
\text { safety }\end{array}$ \\
\hline
\end{tabular}




\begin{tabular}{|c|c|c|c|c|c|}
\hline Authors_ & Study & $\begin{array}{c}\text { Efficiency } \\
\text { (practitioner } \\
\text { performance) } \\
\end{array}$ & $\begin{array}{l}\text { Efficiency } \\
\text { themes }\end{array}$ & $\begin{array}{l}\text { Effectiveness } \\
\text { (medical } \\
\text { outcomes) } \\
\end{array}$ & $\begin{array}{c}\text { Effectiveness } \\
\text { themes }\end{array}$ \\
\hline $\begin{array}{l}\text { Utidjian et } \\
\text { al (26) }\end{array}$ & $\begin{array}{l}\text { Clinical } \\
\text { Decision } \\
\text { Support and } \\
\text { Palivizumab: A } \\
\text { Means to } \\
\text { Protect from } \\
\text { Respiratory } \\
\text { Syncytial Virus. }\end{array}$ & $\begin{array}{l}\text { Proportions of doses } \\
\text { administered declined } \\
\text { during the baseline } \\
\text { seasons (from } 71.9 \% \text { to } \\
62.4 \% \text { ) with partial } \\
\text { recovery to } 67.9 \% \\
\text { during the intervention } \\
\text { season. The } \\
\text { palivizumab-focused } \\
\text { group improved by } 19.2 \\
\text { percentage points in } \\
\text { the intervention season } \\
\text { compared to the prior } \\
\text { baseline season ( } p< \\
0.001 \text { ), while the } \\
\text { comprehensive } \\
\text { intervention group only } \\
\text { improved } 5.5 \\
\text { percentage points ( } p= \\
0.288 \text { ). The difference } \\
\text { in change between } \\
\text { study groups was } \\
\text { significant ( } p=0.05 \text { ). }\end{array}$ & Not discussed & $\begin{array}{l}\text { A quality } \\
\text { improvement } \\
\text { initiative supported } \\
\text { by CDS and } \\
\text { workflow tools } \\
\text { integrated in the } \\
\text { EHR improved } \\
\text { recognition of } \\
\text { eligibility and may } \\
\text { have increased } \\
\text { palivizumab } \\
\text { administration } \\
\text { rates; the } \\
\text { palivizumab- } \\
\text { focused group } \\
\text { performed } \\
\text { significantly better } \\
\text { than a } \\
\text { comprehensive } \\
\text { intervention. }\end{array}$ & $\begin{array}{l}\text { Improved } \\
\text { disease } \\
\text { management }\end{array}$ \\
\hline $\begin{array}{l}\text { Semler et } \\
\text { al (27) }\end{array}$ & $\begin{array}{l}\text { An Electronic } \\
\text { Tool for the } \\
\text { Evaluation and } \\
\text { Treatment of } \\
\text { Sepsis in the } \\
\text { ICU: A } \\
\text { Randomized } \\
\text { Controlled } \\
\text { Trial. }\end{array}$ & $\begin{array}{l}\text { No significant } \\
\text { difference in } \\
\text { performance (also low } \\
\text { utilization of tool) }\end{array}$ & $\begin{array}{l}\text { No difference } \\
\text { reported }\end{array}$ & $\begin{array}{l}\text { No significant } \\
\text { difference: } \\
\text { 1. Mortality } 14.3 \% \\
\text { vs. } 14.9 \% \\
2 . \text { ICU-Free days } \\
17 \text { vs. } 19 \\
\text { 3. Vasopressor free } \\
\text { days } 22.2 \text { vs. } 22.6\end{array}$ & $\begin{array}{l}\text { No } \\
\text { difference } \\
\text { reported }\end{array}$ \\
\hline $\begin{array}{l}\text { Peiris et al } \\
\text { (28) }\end{array}$ & $\begin{array}{l}\text { Effect of a } \\
\text { computer- } \\
\text { guided, quality } \\
\text { improvement } \\
\text { program for } \\
\text { cardiovascular } \\
\text { disease risk } \\
\text { management in } \\
\text { primary health } \\
\text { care: the } \\
\text { treatment of } \\
\text { cardiovascular } \\
\text { risk using } \\
\text { electronic } \\
\text { decision } \\
\text { support cluster- } \\
\text { randomized } \\
\text { trial. }\end{array}$ & $\begin{array}{l}\text { 1. Patients more likely } \\
\text { to receive screening } \\
\text { with CDS ( } 62.8 \% \text { vs. } \\
53.4 \% \text { ) } \\
2 . \text { no improvements in } \\
\text { prescription of } \\
\text { recommended } \\
\text { medications at the end } \\
\text { of the study. }\end{array}$ & $\begin{array}{l}\text { Improved } \\
\text { screening }\end{array}$ & $\begin{array}{l}\text { Improved } \\
\text { cardiovascular } \\
\text { disease risk } \\
\text { management. No } \\
\text { difference in } \\
\text { prescription rates. }\end{array}$ & $\begin{array}{l}\text { Improved } \\
\text { disease } \\
\text { management }\end{array}$ \\
\hline
\end{tabular}




\begin{tabular}{|c|c|c|c|c|c|}
\hline Authors_ & Study & $\begin{array}{c}\text { Efficiency } \\
\text { (practitioner } \\
\text { performance) }\end{array}$ & $\begin{array}{l}\text { Efficiency } \\
\text { themes }\end{array}$ & $\begin{array}{c}\text { Effectiveness } \\
\text { (medical } \\
\text { outcomes) }\end{array}$ & $\begin{array}{l}\text { Effectiveness } \\
\text { themes }\end{array}$ \\
\hline $\begin{array}{l}\text { Chow et al } \\
\text { (29) }\end{array}$ & $\begin{array}{l}\text { Mortality } \\
\text { Benefits of } \\
\text { Antibiotic } \\
\text { Computerized } \\
\text { Decision } \\
\text { Support } \\
\text { System: } \\
\text { Modifying } \\
\text { Effects of Age. }\end{array}$ & $\begin{array}{l}\text { Only } 1 / 4 \text { of patients } \\
\text { received antibiotics } \\
\text { despite } \\
\text { recommendations of } \\
\text { CDSS }\end{array}$ & $\begin{array}{l}\text { More accurate } \\
\text { prescribing }\end{array}$ & $\begin{array}{l}\text { Patients aged } \leq 65 \\
\text { had greater } \\
\text { mortality benefit } \\
\text { (OR 0.45, 95\% CI } \\
0.20-1.00, P=0.05 \text { ) } \\
\text { than patients that } \\
\text { were lder than } 65 \\
\text { (OR 1.28, 95\% CI } \\
0.91-1.82, P=0.16 \text { ). } \\
\text { No effect was } \\
\text { observed on } \\
\text { incidence of } \\
\text { Colostridium } \\
\text { difficile (OR 1.02, } \\
\text { 95\% CI 0.34-3.01), } \\
\text { and multidrug- } \\
\text { resistant organism } \\
\text { (OR 1.06, 95\% CI } \\
\text { 0.42-2.71) } \\
\text { infections. No } \\
\text { increase in } \\
\text { infection-related } \\
\text { readmission (OR } \\
\text { 1.16, 95\% CI 0.48- } \\
\text { 2.79) was found in } \\
\text { survivors. Receipt } \\
\text { of CDSS- } \\
\text { recommended } \\
\text { antibiotics reduced } \\
\text { mortality risk in } \\
\text { patients aged } 65 \\
\text { years or younger } \\
\text { and did not } \\
\text { increase the risk in } \\
\text { older patients. }\end{array}$ & $\begin{array}{l}\text { No } \\
\text { difference } \\
\text { reported }\end{array}$ \\
\hline $\begin{array}{l}\text { Wilson et } \\
\text { al (30) }\end{array}$ & $\begin{array}{l}\text { A randomized } \\
\text { controlled trial } \\
\text { of personalized } \\
\text { decision } \\
\text { support } \\
\text { delivered via } \\
\text { the internet for } \\
\text { bowel cancer } \\
\text { screening with } \\
\text { a faecal occult } \\
\text { blood test: the } \\
\text { effects of } \\
\text { tailoring of } \\
\text { messages } \\
\text { according to } \\
\text { social cognitive } \\
\text { variables on } \\
\text { participation. }\end{array}$ & $\begin{array}{l}\text { Practitioner } \\
\text { performance not } \\
\text { discussed }\end{array}$ & Not discussed & $\begin{array}{l}\text { Improved self- } \\
\text { efficacy and } \\
\text { decreased fecal } \\
\text { aversion }\end{array}$ & $\begin{array}{l}\text { Improved } \\
\text { efficacy }\end{array}$ \\
\hline
\end{tabular}




\begin{tabular}{|c|c|c|c|c|c|}
\hline Authors_ & Study & $\begin{array}{c}\text { Efficiency } \\
\text { (practitioner } \\
\text { performance) }\end{array}$ & $\begin{array}{l}\text { Efficiency } \\
\text { themes }\end{array}$ & $\begin{array}{l}\text { Effectiveness } \\
\text { (medical } \\
\text { outcomes) }\end{array}$ & $\begin{array}{l}\text { Effectiveness } \\
\text { themes }\end{array}$ \\
\hline $\begin{array}{l}\text { Loeb et al } \\
\text { (31) }\end{array}$ & $\begin{array}{l}\text { Evaluation of } \\
\text { the role of } \\
\text { training in the } \\
\text { implementation } \\
\text { of a depression } \\
\text { screening and } \\
\text { treatment } \\
\text { protocol in } 2 \\
\text { academic } \\
\text { outpatient } \\
\text { internal } \\
\text { medicine } \\
\text { clinics utilizing } \\
\text { the electronic } \\
\text { medical record }\end{array}$ & $\begin{array}{l}\text { Training greatly } \\
\text { improved } \\
\text { documentation }\end{array}$ & $\begin{array}{l}\text { Improved } \\
\text { documentation }\end{array}$ & not discussed & $\begin{array}{l}\text { Not } \\
\text { discussed }\end{array}$ \\
\hline $\begin{array}{l}\text { Mishuris } \\
\text { et al (32) }\end{array}$ & $\begin{array}{l}\text { Using } \\
\text { electronic } \\
\text { health record } \\
\text { clinical } \\
\text { decision } \\
\text { support is } \\
\text { associated with } \\
\text { improved } \\
\text { quality of care. }\end{array}$ & $\begin{array}{l}\text { Practitioner } \\
\text { performance not } \\
\text { discussed }\end{array}$ & Not discussed & $\begin{array}{l}\text { Patients who } \\
\text { visited clinics that } \\
\text { were missing at } \\
\text { least } 1 \text { of the CDS } \\
\text { functions were } \\
\text { more likely to have } \\
\text { controlled blood } \\
\text { pressure (86\% vs } \\
82 \%, \text { OR 1.3; 95\% } \\
\text { CI, 1.1-1.5) and } \\
\text { more likely to not } \\
\text { have adverse drug } \\
\text { event visits (99.9\% } \\
\text { vs. 99.8\%; OR 3.0; } \\
\text { 95\% CI, 1.3-7.3). }\end{array}$ & $\begin{array}{l}\text { Improved } \\
\text { symptoms }\end{array}$ \\
\hline $\begin{array}{l}\text { Dexheimer } \\
\text { et al (33) }\end{array}$ & $\begin{array}{l}\text { Implementation } \\
\text { and evaluation } \\
\text { of an } \\
\text { integrated } \\
\text { computerized } \\
\text { asthma } \\
\text { management } \\
\text { system in a } \\
\text { pediatric } \\
\text { emergency } \\
\text { department: a } \\
\text { randomized } \\
\text { clinical trial. }\end{array}$ & $\begin{array}{l}\text { No difference in time to } \\
\text { disposition decision. No } \\
\text { change in hospital } \\
\text { admission rate. No } \\
\text { difference in ED length } \\
\text { of stay. }\end{array}$ & $\begin{array}{l}\text { No difference } \\
\text { reported }\end{array}$ & not discussed & $\begin{array}{l}\text { Not } \\
\text { discussed }\end{array}$ \\
\hline
\end{tabular}




\begin{tabular}{|c|c|c|c|c|c|}
\hline Authors_ & Study & $\begin{array}{c}\text { Efficiency } \\
\text { (practitioner } \\
\text { performance) } \\
\end{array}$ & $\begin{array}{l}\text { Efficiency } \\
\text { themes }\end{array}$ & $\begin{array}{c}\text { Effectiveness } \\
\text { (medical } \\
\text { outcomes) } \\
\end{array}$ & $\begin{array}{l}\text { Effectiveness } \\
\text { themes }\end{array}$ \\
\hline $\begin{array}{l}\text { Heisler et } \\
\text { al (34) }\end{array}$ & $\begin{array}{l}\text { Comparison of } \\
\text { community } \\
\text { health worker- } \\
\text { led diabetes } \\
\text { medication } \\
\text { decision- } \\
\text { making support } \\
\text { for low-income } \\
\text { Latino and } \\
\text { African } \\
\text { American } \\
\text { adults with } \\
\text { diabetes using } \\
\text { e-health tools } \\
\text { versus print } \\
\text { materials: a } \\
\text { randomized, } \\
\text { controlled trial. }\end{array}$ & $\begin{array}{l}\text { Practitioner } \\
\text { performance not } \\
\text { discussed }\end{array}$ & Not discussed & $\begin{array}{l}\text { Decrease in } \\
\text { diabetes distress, } \\
\text { but no difference in } \\
\text { other outcomes. }\end{array}$ & $\begin{array}{l}\text { Improved } \\
\text { symptoms }\end{array}$ \\
\hline $\begin{array}{l}\text { Eckman et } \\
\text { al (35) }\end{array}$ & $\begin{array}{l}\text { Integrating } \\
\text { real-time } \\
\text { clinical } \\
\text { information to } \\
\text { provide } \\
\text { estimates of } \\
\text { net clinical } \\
\text { benefit of } \\
\text { antithrombotic } \\
\text { therapy for } \\
\text { patients with } \\
\text { atrial } \\
\text { fibrillation. }\end{array}$ & $\begin{array}{l}\text { Decisions are based on } \\
\geq .1 \text { QALYs; the tool } \\
\text { identified } 50 \% \text { that } \\
\text { would benefit from this } \\
\text { threshold }\end{array}$ & $\begin{array}{l}\text { Improved } \\
\text { performance }\end{array}$ & $\begin{array}{l}\text { Significant gain in } \\
\text { quality-adjusted life } \\
\text { expectancy }\end{array}$ & $\begin{array}{l}\text { Improved } \\
\text { mortality }\end{array}$ \\
\hline $\begin{array}{l}\text { Zaslansky } \\
\text { et al (36) }\end{array}$ & $\begin{array}{l}\text { PAIN OUT: an } \\
\text { international } \\
\text { acute pain } \\
\text { registry } \\
\text { supporting } \\
\text { clinicians in } \\
\text { decision } \\
\text { making and in } \\
\text { quality } \\
\text { improvement } \\
\text { activities. }\end{array}$ & $\begin{array}{l}\text { Audit and feedback and } \\
\text { benchmarking are } \\
\text { provided to } \\
\text { practitioners to identify } \\
\text { when their practice is } \\
\text { not in line with the } \\
\text { data. }\end{array}$ & $\begin{array}{l}\text { Improved } \\
\text { benchmarking }\end{array}$ & $\begin{array}{l}\text { Provides real-time } \\
\text { feedback on PROs }\end{array}$ & $\begin{array}{l}\text { Improved } \\
\text { feedback }\end{array}$ \\
\hline
\end{tabular}




\begin{tabular}{|c|c|c|c|c|c|}
\hline Authors_ & Study & $\begin{array}{c}\text { Efficiency } \\
\text { (practitioner } \\
\text { performance) } \\
\end{array}$ & $\begin{array}{l}\text { Efficiency } \\
\text { themes }\end{array}$ & $\begin{array}{l}\text { Effectiveness } \\
\text { (medical } \\
\text { outcomes) } \\
\end{array}$ & $\begin{array}{c}\text { Effectiveness } \\
\text { themes }\end{array}$ \\
\hline $\begin{array}{l}\text { Lobach et } \\
\text { al (37) }\end{array}$ & $\begin{array}{l}\text { A Randomized } \\
\text { Trial of } \\
\text { Population- } \\
\text { Based Clinical } \\
\text { Decision } \\
\text { Support to } \\
\text { Manage Health } \\
\text { and Resource } \\
\text { Use for } \\
\text { Medicaid } \\
\text { Beneficiaries. }\end{array}$ & $\begin{array}{l}\text { No treatment-related } \\
\text { differences between } \\
\text { groups }\end{array}$ & $\begin{array}{l}\text { No difference } \\
\text { reported }\end{array}$ & $\begin{array}{l}\text { Among patients } \\
<18 \text { years, those in } \\
\text { the email group } \\
\text { had fewer low } \\
\text { severity ( } 7.6 \text { vs. } \\
10.6 / 100 \text { enrollees, } \\
\text { p<0.001) and total } \\
\text { emergency } \\
\text { department } \\
\text { encounters (18.3 } \\
\text { vs. } 23.5 / 100 \\
\text { enrollees, } \\
\text { p<0.001), and } \\
\text { lower emergency } \\
\text { department ( } \$ 63 \\
\text { vs. } \$ 89, p=0.002) \\
\text { and total medical } \\
\text { costs ( } \$ 1,736 \text { vs. } \\
\$ 2,207, p=0.009) \text {. } \\
\text { Patients who were } \\
\geq 18 \text { years in the } \\
\text { letter group had } \\
\text { greater outpatient } \\
\text { medical costs. }\end{array}$ & $\begin{array}{l}\text { Improved } \\
\text { symptoms }\end{array}$ \\
\hline $\begin{array}{l}\text { Barlow \& } \\
\text { Krassas } \\
(38)\end{array}$ & $\begin{array}{l}\text { Improving } \\
\text { management of } \\
\text { type } 2 \text { diabetes } \\
\text { - findings of the } \\
\text { Type2Care } \\
\text { clinical audit }\end{array}$ & $\begin{array}{l}\text { Annual cycle of care } \\
\text { plans increased by } \\
12 \% .\end{array}$ & $\begin{array}{l}\text { Improved care } \\
\text { plans }\end{array}$ & $\begin{array}{l}\text { Patients better } \\
\text { able to meet } \\
\text { targets for } \\
\text { Microalbumin. } \\
\text { Glycemic control } \\
\text { well managed. }\end{array}$ & $\begin{array}{l}\text { Improved } \\
\text { symptoms }\end{array}$ \\
\hline $\begin{array}{l}\text { Robbins et } \\
\text { al (39) }\end{array}$ & $\begin{array}{l}\text { Efficacy of a } \\
\text { clinical } \\
\text { decision- } \\
\text { support system } \\
\text { in an HIV } \\
\text { practice: a } \\
\text { randomized } \\
\text { trial. }\end{array}$ & $\begin{array}{l}90 \% \text { of providers } \\
\text { involved with the RCT } \\
\text { supported adopting the } \\
\text { intervention }\end{array}$ & $\begin{array}{l}\text { Improved buy- } \\
\text { in of CDSS }\end{array}$ & $\begin{array}{l}\text { increased CD4 } \\
\text { positive lymphocyte } \\
\text { count and reduced } \\
\text { suboptimal follow- } \\
\text { up appointment. }\end{array}$ & $\begin{array}{l}\text { Improved } \\
\text { symptoms }\end{array}$ \\
\hline $\begin{array}{l}\text { Chen et al } \\
(40)\end{array}$ & $\begin{array}{l}\text { Developing } \\
\text { guideline-based } \\
\text { decision } \\
\text { support } \\
\text { systems using } \\
\text { protégé and } \\
\text { jess. }\end{array}$ & $\begin{array}{l}\text { New CDSS identified } \\
70 \text { records that needed } \\
\text { reassessment of } \\
\text { triglycerol (TG) level }\end{array}$ & $\begin{array}{l}\text { Improved } \\
\text { screening }\end{array}$ & not discussed & $\begin{array}{l}\text { Not } \\
\text { discussed }\end{array}$ \\
\hline
\end{tabular}




\begin{tabular}{|c|c|c|c|c|c|}
\hline Authors_ & Study & $\begin{array}{c}\text { Efficiency } \\
\text { (practitioner } \\
\text { performance) }\end{array}$ & $\begin{array}{l}\text { Efficiency } \\
\text { themes }\end{array}$ & $\begin{array}{c}\text { Effectiveness } \\
\text { (medical } \\
\text { outcomes) } \\
\end{array}$ & $\begin{array}{c}\text { Effectiveness } \\
\text { themes }\end{array}$ \\
\hline $\begin{array}{l}\text { Seow et al } \\
(41)\end{array}$ & $\begin{array}{l}\text { Perspectives of } \\
\text { patients on the } \\
\text { utility of } \\
\text { electronic } \\
\text { patient- } \\
\text { reported } \\
\text { outcomes on } \\
\text { cancer care. }\end{array}$ & $\begin{array}{l}\text { 87\% of respondents } \\
\text { strongly agreed or } \\
\text { somewhat agreed that } \\
\text { the "ESAS was } \\
\text { important to complete } \\
\text { because it helped the } \\
\text { health care team to } \\
\text { know what symptoms } \\
\text { [they] were having and } \\
\text { how severe they were." }\end{array}$ & $\begin{array}{l}\text { Improved } \\
\text { screening }\end{array}$ & $\begin{array}{c}79 \% \text { of } \\
\text { respondents rated } \\
\text { that their "pain and } \\
\text { other symptoms } \\
\text { have been } \\
\text { controlled to a } \\
\text { comfortable level" } \\
\text { always or most of } \\
\text { the time compared } \\
\text { with 8\% of } \\
\text { respondents who } \\
\text { rated this as rarely } \\
\text { or never occurring }\end{array}$ & $\begin{array}{l}\text { Improved } \\
\text { symptoms }\end{array}$ \\
\hline
\end{tabular}

Table 2: Summary of themes identified for practitioner performance

Efficiency Themes $\quad$ Occurrences Incidence of Occurrence Prob of Occurrence

\begin{tabular}{lllc}
\hline More accurate prescribing & $19,23,29$ & 3 & $11 \%$ \\
\hline Improved screening & $28,40,41$ & 3 & $11 \%$ \\
\hline Improved performance & 35 & 1 & $4 \%$ \\
\hline Increased awareness & 15 & 1 & $4 \%$ \\
\hline Better follow up with pts & 18 & 1 & $4 \%$ \\
\hline Improved accuracy & 25 & 1 & $4 \%$ \\
\hline Improved documentation & 31 & 1 & $4 \%$ \\
\hline Improved benchmarking & 36 & 1 & $4 \%$ \\
\hline Improved care plans & 38 & 1 & $4 \%$ \\
\hline Improved buy-in of CDSS & 39 & 1 & $4 \%$ \\
\hline No difference reported & $27,33,37$ & 3 & $11 \%$ \\
\hline Not discussed & $16,17,20-22,24,26,30,32,34$ & 10 & $37 \%$
\end{tabular}

Table 3: Summary of themes identified for patient medical outcomes 


\begin{tabular}{llcc}
\hline Improved symptoms & $18,32,34,37-39,41$ & 7 & $26 \%$ \\
\hline Improved efficacy & 24,30 & 2 & $7 \%$ \\
\hline $\begin{array}{l}\text { Improved disease } \\
\text { management }\end{array}$ & 26,28 & 2 & $7 \%$ \\
\hline Improved safety & 25 & 1 & $4 \%$ \\
\hline Improved mortality & 35 & 1 & $4 \%$ \\
\hline Improved screening & 22 & 1 & $4 \%$ \\
\hline Improved feedback & 36 & 1 & $4 \%$ \\
\hline No difference reported & 27,29 & 2 & $7 \%$ \\
\hline Not discussed & $15-$ & 10 & $37 \%$ \\
\hline
\end{tabular}

\section{Figures}




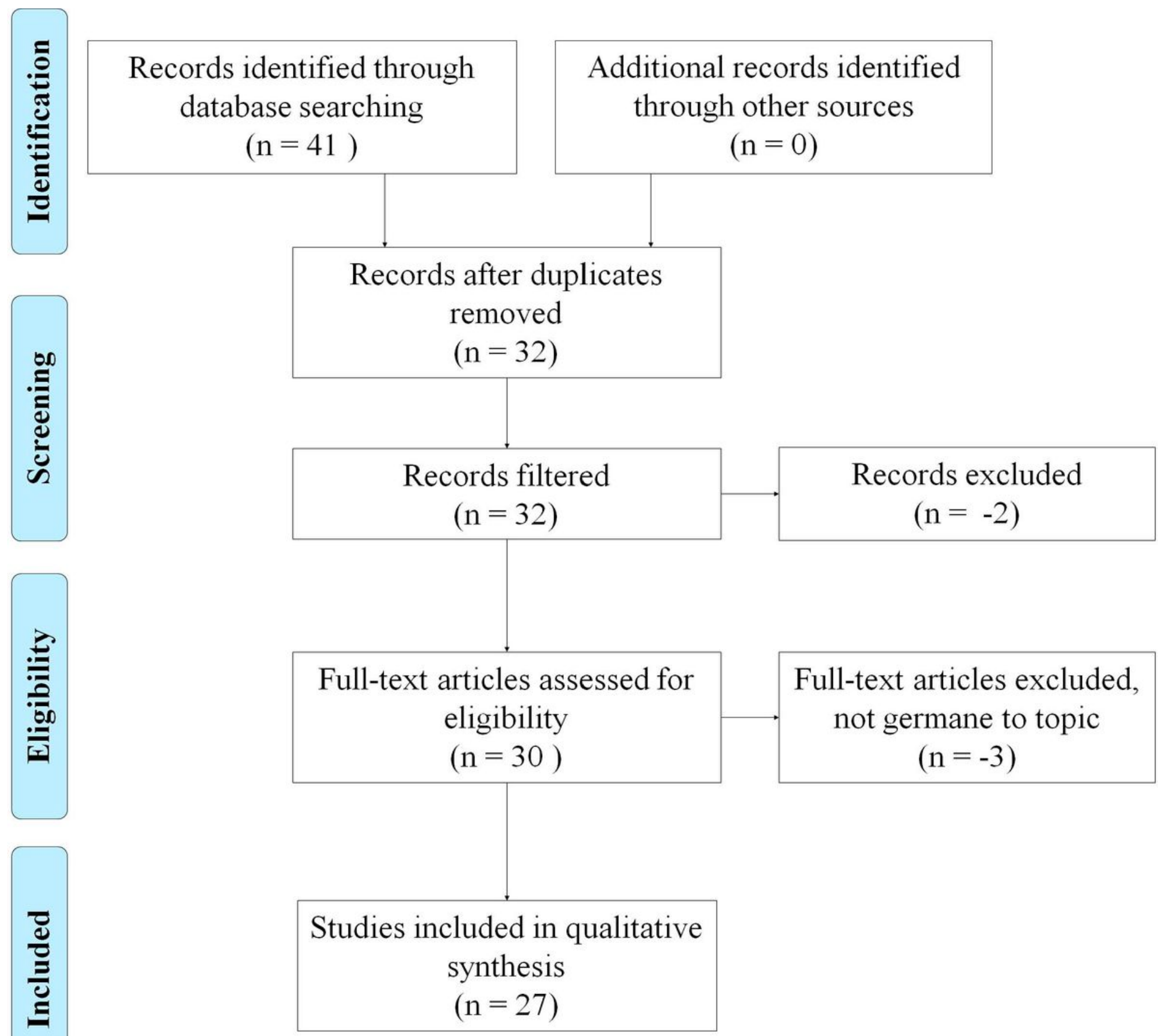

Figure 1

This figure portrays the PRISMA flow diagram including the records identified through databases, the number screened out, full-text articles assessed for eligibility, and final group chosen for analysis. 